\title{
The Dyestuffs Industry in Relation to Research and Higher Education. ${ }^{1}$
}

\section{By Dr. Herbert Levinstein.}

W

ITHIN one generation we have seen the small mechanics' institute in a provincial city develop into an institution of university standing, constituting a technological faculty giving degrees, with some of its professors sitting on the university senate. In one way or another London, Birmingham, Bristol, all the large cities, show the same change. It means that within this period an enormous change has taken place in the character and requirements of our industries, and consequently in the demand for highly trained young men. The industrial world has changed. The present characteristic of industry is the tendency towards large units, using as one of their weapons an intelligence department (a research department), equipped with every resource of science. This is in itself nearly as far removed from the Victorian system of industry as that was from its predecessor, and it is causing nearly as great a social change as the industrial revolution that followed on the introduction of machinery.

The scientific educational establishments in this country are fundamental to the whole structure. By the vitality and originality, by the number and the quality of our teachers, the world can judge of the capacity of Great Britain in the long-neglected scientific industries, of which dyestuffs and fine chemicals are pre-eminent.

The dyestuffs industry is what is loosely termed a key industry. Mr. Runciman, speaking in the House of Commons on November 27, I9I4, said: "The combined capital of such operations of textile and other industries which require aniline dyes comes to no less than 200,000,000l., and about 1,000,000 of our employees are either directly or indirectly interested in the adequate supplies of dyestuffs for their main industries." There were few people who questioned at that time the urgency and importance of producing within our own shores the commodities required to support so many staple industries. We were at war with Germany, on whom we had been dependent in peace time for 80 per cent. of our requirements, and at that moment it was necessary, both from an economic and military point of view, to replace at once those vanished supplies from home sources.

What happened after the War? In I9I3 the dyestuffs industry in England supplied about Io per cent. of the British consumption, which amounted in round figures to rather more than 20 , ooo tons. The factories were comparatively small, and the number of chemists proportionately few. By Armistice Day the two principal companies, already loosely united, employed some 7000 persons, nearly 300 of whom were academically trained chemists-an unheard-of number in this country. During the two years following the Armistice more than 25,000 tons of dyestuffs manufactured by this British company alone went into consumption in Great Britain.

The extraordinary prosperity in the textile trades at that period had its aftermath in the slump. In I9I9, however, the employment provided by these trades, and the money brought into this country as payment for exports, were factors without which this country would not have readily recovered from the paralysis of war. The total value of the exports of printed and cotton dyed piece goods alone during I919-20 amounted to 270 million pounds sterling. In October I920 the British Dyestuffs Corporation alone employed some 8000 people, with a yearly wage roll of $1,600,000 l$. This company used 4000 tons of

${ }^{1}$ From a paper read before the Association of Technical Institutions on March 3.

NO. 2787 , VOL. II I ] coal per week, Iooo tons of pyrites, and corresponding quantities of heavy chemicals and raw materials. These figures may be considered large in this country, where we are not so familiar with very large plańts, but they are small compared with the aggregate of the German I.G.

Suddenly in October I920 the slump fell upon the country. The position was made much worse by four factors. German production revived, considerable quantities of German dyes were imported as reparations, the Sankey judgment temporarily removed all protection from the home producer, and the rapid external depreciation of the mark temporarily made it difficult to compete with Germany in neutral markets. Stocks fell in value, large sums of money were lost, and the production of British companies fell almost to pre-war figures.

The dyestuff and fine chemical industries in this country, are by no means assured of a prosperous, development. If the factories are allowed to decay, the staffs to be gradually diminished, the capital invested rendered unremunerative, our position will become less strong. At the moment, should the occasion arise, the factories and organisations created during the war years are a source of strength.

The developments of higher scientific education in this country, on which our scientific industry is based, tend to strengthen the national life in a way which may not be immediately obvious but yet quietly and unobtrusively may be of fundamental importance to the State. There is another reason of great importance in favour of a flourishing and progressive dye industry. The dye industry is a key industry to invention. Its importance as a factor in producing new inventions is well summarised by Mr. J. A. Choate, the author of an official American publication issued by the Alien Property Custodian of the United States Chemical Section :

"The Technical skill and equipment provided by a successful Dye Industry, furnishes the means, and almost the sole means, to which every nation must look for advances in the application of chemical science to practical undertakings. No other industry offers a livelihood to any such large numbers of highly trained scientific chemists nor any such incentive to continuous and extended research."

Any firm wishing to become a serious factor in the world's markets for fine chemicals and dyes must employ a number of research chemists. Existing products tend towards obsolescence, competition from other makers tends to lower their price, and new demands constantly arise and are satisfied or created by new products for which high prices can be obtained owing to their novelty and, at first, the absence of competition. In the long run that nation will predominate in this industry which brings out the best and the largest number of new products.

These research organisations are expensive. Why then did the Germans start in this race for new products? They found this kind of research to be extremely profitable to their shareholders. Consequently, it was developed, and they were able to bring out annually quite a number of new products which, pushed by enterprising salesmen in all markets, home and foreign, gradually became established branches of manufacture in Germany.

Research for new products costing no more than the old, but for which the public will pay a higher price, is intimately wrapped up with the question of patents. Without the prospect of a monopoly for a term of vears, and the lure of high profits, this kind of 
work would not be undertaken on a comprehensive scale. Unfortunately, the monopolies granted in our country in the past for this kind of work were granted to German industries, and not to our own, and large profits were made out of British patents by the German dyestuff works. A similar research system, if sufficiently supported on the commercial and technological side and directed with sufficient knowledge of the requirements of the industry, and with some imagination, can be made to pay in England just as in Germany, where this combination existed. It is important to remember that firms employing this modern commercial weapon were large, for the amount of money that can be spent on research is a function of the turnover.

It is further true that to build laboratories, to engage for them a number of chemists, are not alone sufficient for our success.

If the stream of chemical invention can be induced to flow in this country in the future not less sluggishly than in Germany, we shall gradually build up new industries as the Germans built up theirs.

In this country we rely too much on our staple industries and look too little for new inventions to find food and employment for our people. In the Report of the Department of Scientific and Industrial Research, r92I-22:

It is well recognised that for four-fifths of their food and for a great part of the necessary raw and semi-manufactured materials for industry the people of these-islands are dependent on supplies from overseas. These supplies can only be obtained if this country is able to carry on its exporting industries in future with greater efficiency than the rest of the world."

The Department spent in this year more than half a million pounds with this purpose in view, and provision is made for expenditure on a similar scale for the current year. Under its auspices no less than 24 Industrial Research Associations have been formed, of which 22 are licensed by the Department, and received more than $86,000 \mathrm{l}$. in grants during the year in question. Broadly speaking, the work of the Department and of the Research Associations with which it collaborates is to ensure the best utilisation of our natural resources and of the raw materials which we buy from abroad for our staple industries, with the view of increasing the efficiency of those industries and enlarging the demand for their products in customer countries.

This work does not replace that of private firms, but is complementary to and ought to stimulate it. There is a radical difference between industrial research carried out by a company and that by a Research Association, or by a Department of State. Patents taken out by chemists who receive part of their emoluments from the Department, belong apparently to the Government. Patents which may be taken out by a Research Association would presumably be available for all subscribers and could not easily become a profitable monopoly for any one member. For this reason it appears likely that in the future, as in the past, the dyestuffs industries and the allied fine chemical industries will be the main source from which chemical discoveries will be transferred from the laboratory to the factory.

Running through all this is one common factor which must be realised if the expectations of the State are to be satisfied. The industry must be big. There must be large factories containing plant capable of producing great quantities of organic chemicals, staffed by an adequate number of experienced and welltrained chemists. Moreover, the factories must be growing. It is an industry which cannot succeed if it be static. It must be ever increasing its plant and the number of its chemists and ever spreading its tentacles wider and deeper into the markets of the world.

It follows that if the industry is successful there will be a continual flow of students from the universities and technical schools to the industry. Two distinct classes of chemical students are required: (a) for factory and research, and $(b)$ for the dyehouse and technical sales. It is customary in aniline dyestuff factories to recruit the chemists for plant supervision from their own research department. The young chemist engaged on leaving the university is first placed in the research department for at least a year before a permanent engagement is made. The training required of a dyestuff works chemist is usually identical, whether he intends to devote himself afterwards purely to research, or, as in the majority of cases, to become actually employed in the factory. It is of the first importance that chemists should have a good general secondary education. After taking his degree the student should cary out, under direction, original work for one or, preferably, two years. What branch of organic chemistry he studies is comparatively immaterial. A special knowledge of dyestuffs chemistry is not very important.

Undoubtedly a knowledge of chemical engineering is useful, but subjects added; however useful, will be at the expense of chemistry. The recent formation of the Institution of Chemical Engineers is welcome. Good chemical engineers are invaluable in any chemical industry, but, above all, good organic chemists are wanted in the dyestuff industry.

There is also a considerable demand for another type of chemist. All aniline dye works have a dyehouse which fulfils a treble function-the control of the production, the valuation of new specimens sent in from the research department, and the supply to the sales organisation of technical information and assistance in the application of dyestuffs. The technical salesman is a person of great importance in the industry. He should preferably take a pure or technological science degree, followed by a course in dyeing, printing, paper-making, etc., at a technical college. There is a constant demand for such men in a flourishing dyestuffs industry, the more so as the experience obtained in the experimental dyehouse is so varied, that such men are afterwards sought for as managers or as assistant managers in print-works, dyehouses, paper-works, and the like.

The foundation stones of our scientific industries were laid by those responsible for the creation of our great technical institutions and University Colleges. If that is so, we should expect to see during the years which have elapsed since I $9 \mathrm{r} 4$ a corresponding development in the chemical schools of this country. The progress in the study, teaching, and research in pure chemistry has been at least as striking as the progress of those sections of chemical industry such as fine chemicals and dyestuffs in which we were not particularly strong before the War. Twenty or thirty years ago the German organic schools were as pre-eminent in research and in teaching as the German dyestuff and fine chemical industry. To-day one may fairly say that there are several organic chemical schools in this country equal to that of any organic chemical school in Germany. Brilliant original work is being done here. Students are attracted to schools where good research is being done, and so round each head is formed a coterie of young men deriving inspiration from their chief, to strengthen the ranks of industry. Probably there has never been such a concentration of chemical talent as that which gathered round A. von Baeyer in Munich thirty or forty years ago, but something of the kind is happening in Great Britain to-day, and not in one centre alone.

Thirty years ago, institutions comparable, for

NO. 2787 , VOL. I I I ] 
example, with the Federal Polytechnic at Zurich or the Technical High School of Charlottenburg did not exist in Great Britain. The scale on whch they were designed, their large staffs of distinguished teachers, the number of full-time students, students who had remarkably good secondary school training and had passed a rigorous entrance examination, astonished all English visitors. The English organic chemist with industrial experience was equally astonished at, for example, the Leverkusen or the Badische factories. These factories differed from the corresponding English factories in scale, in the size of the buildings, their staffs, their financial results, just as the British schools differed from the corresponding German institutions.

The number of students taking a degree in pure science at 17 English and Welsh Universities in I9I3I9I4 was I867. In I92I-22 the number was 4575 , i.e. about two and a half times the $\mathrm{I}_{91} 3^{-} \mathrm{r}_{4}$ number. At the University of Cambridge the figures were as follows :

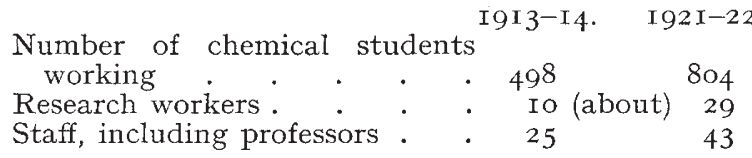

The growth of the dyestuffs industry within this period is well known, and there has been a similar growth in the fine chemical industry. In I9I3 some Ioo fine chemicals were made in England, whereas 4000 are now being made; for every ton of fine chemicals made here in $19 \mathrm{I}_{3}$ exactly $2 \frac{1}{2}$ tons are made to-day. This ratio is identical with that of the increase in science students taking a degree course.

Is it possible that this parallel growth in our teaching institutions and newer industries is accidental? The figures are symptomatic, but they indicate that the strength of our higher teaching bodies is a measure of our strength in the industries depending on invention.

It may be said that there has been in Germany, too, and no doubt in other countries, a great increase in the number of students at their High Schools. In part this is one of the social changes brought about by the new industrial revolution.

The increase in the number of chemical students is partly due to the publicity given in I9I4 to the renascent dyestuffs industry, and to the support given by public opinion and by the Press for the first time in our history to those engaged in these industries. These industries open out to a young man who has a love of research the opportunity of earning a livelihood in a most interesting way, with the added possibility, if his inventions prove commercially successful, of earning considerable profits. Before the War it was difficult to live by research.

It is probable that the grants made by the Department of Scientific and Industrial Research have tended to increase the number of chemists undertaking training, "for the underlying object of the Scheme of Grants is the output of an increased number of trained scientific investigators." At the same time, the Department has done much to increase the possibility of finding employment for chemists. The Department, including its headquarters staff, boards and committees, Fuel Research Station and the Research Associations, already employs $7^{8}$ chemists, none of whom were employed in I913, at salaries ranging from about $25 \mathrm{ol}$. to $2000 \mathrm{l}$, the majority between $35 \mathrm{ol}$. and 7ool. In other Government Departments, too, there has been a great increase in the number of chemists employed. In I9I3-I4 the staff of the Government Chemist consisted of 48 , with a salary range of $120 l$. rising to $\mathrm{I} 5 \mathrm{ool}$. The majority of the posts ranged from $120 l$. to $500 l$. In $192 \mathrm{I}-22$ there were 75 posts, ranging in salary from $300 l$. to $700 l$. At the War Office in I9I $3^{-1} 4$ there were 22 posts and 2 teaching posts at the Ordnance College. The salary range was about $15 \mathrm{Ol}$. to $55 \mathrm{O}$. In $\mathrm{I} 92 \mathrm{I}-22$ there were 93 posts, with salaries ranging from $300 l$. up to $1200 l$., but with the majority falling within a range of $300 l$. to $700 l$. At the Admiralty in I9I-I 4 there was one inspector of cordite, in addition to the teaching staff at the Royal Naval College at Greenwich and the schools at Dartmouth and Osborne. In $192 \mathrm{I}-22$, in addition to these teaching staffs, there were 20 posts with salaries of from about I $50 l$. to $600 \mathrm{l}$. The total number of chemists who can to-day find employment in the service of the above Government Department is thus I93 more than in r9I3.

In the I92I report of the Department it is stated that of the 132 students receiving grants 24 found employment under the State or under State-aided research institutions, 22 went into the teaching profession, and none went into industry, no doubt owing to the slump in trade.

If our fine chemical industries begin to increase their staffs regularly, as in prosperous years they will, the situation will be improved, but it is to the general trade of the country and not to the specifically chemical industries that we must look to give employment to all those who have taken a chemical degree.

\section{Large Telescopes and their Work.}

SIR FRANK DYSON'S presidential address to the Optical Society on February 8 on the subject of "Large Telescopes" dealt with the progressive advance of astronomy so far as it was brought about by the increased optical powers of telescopes. The Copernican system was established before the discovery of the telescope, but Galileo's telescope removed many difficulties and commanded its acceptance. The great telescopes of Herschel revealed the vast extent and variety of the stellar system. At the beginning of the nineteenth century, excellent achromatic telescopes of 6 inches were made by Fraunhofer and Merz, and in I824 an object glass of 9.6 inches was made for Struve at Dorpat with which he carried out his great work on double stars.

When the Russian National Observatory at Polkovo was founded a I5-inch glass was obtained from the Munich firm, and this was the largest refractor in the middle of the nineteenth century. The large telescopes of this time were the reflectors of Lord
Rosse and Lassell, and with them the heat from the moon was measured and new satellites of Uranus and Neptune discovered. A new development in reflecting telescopes came with the process of silvering on glass, and gradually these superseded speculum. In England in the early 'eighties photography of nebulæ began with Common's photograph of the Orion nebula, and was pursued by Isaac Roberts. The manufacture and mounting of reflectors was brought to a high degree of perfection by Ritchey at the Yerkes Observatory, but it was with the Crossley reflector, made by Calver and presented to the Lick Observatory by Sir Edward Crossley, and remounted by Keeler, that most systematic work was done.

Meanwhile, larger refractors were being made. In I 868 one of 26 inches aperture was made by Cooke for H. S. Newall of Newcastle. This was soon followed by large telescopes in America by Alvan Clark, by Grubb in England, and the brothers Henry

$$
\text { NO. } 2787 \text {, VOL. I I I] }
$$

